\title{
RITUALISM AS A REFLECTION OF SOCIAL TRANSFORMATION AND THE RESEARCHER'S (LACK OF) POWER
}

\section{MARIJA KLOBČAR}

This paper describes various views of the Kamnik folklore event Traditional Costume and Clothing Heritage Days in order to illuminate the relationship researchers have with these cultural phenomena. It analyzes the origins of the Kamnik event, revealing its social significance, and also analyzes the reasons that this event has attained ritual status for some. Although the event still plays this role today for some people, it has gradually also gained completely different meanings. The researcher is present as an observer, but also as an advisor when asked by the organizers, at which point he is faced with numerous issues connected with the concept of authenticity. This article therefore places the researcher's role within the context of views that problematize his a priori position and call attention to the fact that the researcher should participate at the level of informer. Considering the varied meanings this event has for individuals, and considering their diverse relations to folklorism, which are recognized in both the organizers and the participants, the question is which of these views ought to be taken into account.

Keywords: group-specific costume, ritualism, authenticity, folklorism, Kamnik
Prispevek z upodobitvijo različnih pogledov na kamniško folkloristično prireditev Dnevi narodnih noš in oblačilne dediščine odpira vprašanja odnosa raziskovalcev do teh kulturnih fenomenov. $Z$ analizo geneze kamniske prireditve razkriva njene družbene pomene, hkrati pa analizira razloge za to, da je prireditev v očeh nekaterih dobila pomen rituala. Medtem ko ima prireditev Dnevi narodnih noš in oblačilne dediščine za nekatere to vlogo še danes, je postopno dobivala tudi povsem drugačne pomene. Raziskovalec je ob tem opazovalec, na željo prirediteljev pa tudi svetovalec, pri čemer se sooča šstevilnimi dilemami, povezanimi z vprašanji avtentičnosti. Prispevek zato vlogo raziskovalca postavlja $v$ kontekst tistih pogledov, ki problematizirajo njegovo apriorno pozicijo in opozarjajo na to, da bi moral raziskovalec stopiti na raven informatorjev. Glede na različne pomene, ki jih ima prireditev za posameznike, in glede na različne odnose do folklorizma, ki jih prispevek prepoznava tako pri prirediteljih kot pri udeležencih, se sprašuje, katerega od teh pogledov naj ob tem upošteva.

Ključne besede: pripadnostno kostumiranje, ritualnost, avtentičnost, folklorizem, Kamnik

In early 1996, I was surprised by an angry phone call: an older woman called me without even introducing herself. She told me that she came in contact with "folk costumes" from her town ${ }^{1}$ on a weekly basis and that all the members of the local folk group were awfully mad at me. The reason for their anger, which was also strongly expressed verbally, was a photograph I had published in the anniversary newsletter for the 25th Traditional Costume and Clothing Heritage Days (Dnevi narodnih noš in oblačilne dediščine) in Kamnik. ${ }^{2}$ The woman concluded her tirade, peppered with offensive words and accompanied by a lecture on what really belonged to a traditional costume, with the following: "Do you even know what a traditional costume is?"

1 I have withheld the name of the town on purpose.

2 Translated as "Days of National Costumes and Clothing Heritage" on their website (http://www.cioff. org/events-festival.cfm/en/4400/Slovenia-Days_of_National_Costumes_and_Clothing_Heritage_-Kamnik, 15. 5. 2012). This is a tourism and folklore event that has been taking place in Kamnik since 1966. Initially it only included a ceremonial folk-costume procession, but over the years it has increased in size and scope; this also influenced the various changes in the event's name. 


\section{PHOTOGRAPHS AS CHALLENGES OR REVEALED RITUALISM}

I took the photograph in question at the 1994 Kamnik traditional-costume festival. After the ceremonial procession, I took a photo of a girl riding a bike while wearing a traditional costume. ${ }^{3}$ However, the reason for all the uproar was not because I had violated the privacy of the person in the photo. This would have been a perfectly understandable reason, even though we did not know much about privacy protection back then. What I was blamed for was the fact that I took a photo of a traditional costume at a moment when the wearer was not acting in line with people's notions about what a person wearing clothing that signified affiliation to a particular group should be doing.

I was even more hurt by this phone call because I was not responsible for the publication of this photo in the first place: it was published without my permission. I myself was unpleasantly surprised to see the photo in the newsletter because it was completely clear to me that it conveyed messages that differed completely from those the anniversary newsletter sought to convey and, most importantly, it was published without any commentary. As shown by the anonymous phone call, the discontent with its publication was completely justified. During the telephone conversation itself I was unable to get a word in edgewise to explain anything at all regarding the photograph and its publication. The woman that called needed no explanation because she had a clear idea of how people wearing traditional costumes and those observing or writing about them should behave. During this verbal attack that did not allow me to defend myself, the following thought struck me: only believers in the sanctity of traditional costumes can act this way. My violation was a violation of the sacredness of the traditional costume, against the ritual that people were only allowed to see in the form in which it has been presented to the audience in front of an invisible altar of history. The phone call was very offensive and it hurt my feelings, but at the same time it also gave me an extremely good idea of people's expectations concerning the ethnologist's role in folklore events. Actually this viewpoint was fairly similar to one ten years before, which sought to include me in the event's preparations: the tourism society that organized the event that year needed an expert or an ethnologist to judge what belonged to traditional costumes and how people were supposed to behave when wearing a group-specific costume. Because I was already beginning to study Kamnik at the time, I did not refuse the work, but despite the organizers' expectations I maintained a dual attitude towards the event during the entire period of my observation. As an ethnologist, I followed the event as a modern phenomenon, but at the same time, in line with the organizers' request, I explained the meaning of using costumes in the past and present in special publications and in the

3 This was a "group-specific costume" (Sln. pripadnostni kostum; Knific 2008, 2010); that is, a cultural phenomenon that is difficult to name due to its social role. From the standpoint of its bearers, this is a "folk" or "traditional" costume. Instead of using the term "folklore costume," which is currently in vogue, I prefer to use the term "traditional costume." The term "folklore" in this situation encompasses an evaluation of authenticity, which I prefer to avoid for the reasons discussed in this article. 
media (Klobčar 1984, 1985, 1990, 1995). An explanatory role was also played by a special exhibition that showed the attitude towards traditional costumes by analyzing the private collection of Mara Pucelj, who was among those that founded this event (Klobčar 1992). Both the role of the observer and the role of the advisor or interpreter were interconnected: in my observations and interpretations of the events connected with Folk Costume Days I could not exclude the ethnological view. Nonetheless I retained a certain degree of selfcontrol in conveying these views: I knew that I could not express all of my observations in my reports. However, the observation itself could not have this self-control. Regardless of the fact that the photo showing the girl on the bike was published without my knowledge, I took this photo on purpose-almost impulsively, because I did not have time to adjust the analogue camera, which is why the photo is not good quality. I was happy to see the girl riding a bike in a traditional costume because it very illustratively showed the other side of folklorism. It reflected an ethnologist's view and also relativized the view that the participants thought I was supposed to have as an expert advisor for this event.

The anonymous phone call thus forced me to thoroughly reflect on the matter, even though I had already been dealing with these issues for quite some time. By following the event and having spontaneous conversations with their organizers and participants, I gradually got to know why this event had become so popular in Kamnik. After analyzing the meanings I had identified in the procession, I concluded my views on the event in the anniversary newsletter, in which the controversial photo was also published, in the following manner: "The Kamnik traditional-costume procession is thus a special reflection of today's needs rather than the periods that ascribed individual meanings to the costumes. It is a reflection of the diversity of meanings it hides or reveals, and a special challenge to the relationship to one's own town. During Traditional Costume Days, life in Kamnik is completely different: people walk around the town without hurrying, chat with one another as if they had never become alienated from each other, and feel that Kamnik is their town. This is why during these days Kamnik speaks not only in the language of costumes, but also in a language of streets and squares filled with life again and a relaxed atmosphere" (Klobčar 1995: no page).

However, the phone call by the representative of the Kamnik procession participants had a different message: whoever reports about the event must feel the same thing as the participants. My photo thus violated their vision of the event's authenticity. Despite the offensiveness of their call, I identified an image of internalized authenticity in the message: "The question of internalized authenticity - the authentic human experience, the exuberant search for the 'soul of the people,' as Herder called it - is a much more complex temptation, an attractive, troubling series of attempts to pinpoint the ineffable" (Bendix 1997: 7). This raised the question of internalized images that can be so clear only because they reject any relativization. My violation was completely clear in this regard: I took a photo of an image that did not suit these people's idea of a "traditional costume." But nonetheless there was only one call. Can we thus talk about a general idea, or are there several? 


\section{THE TRADITIONAL-COSTUME PROCESSION IN KAMNIK AS AN URBAN RITUAL AND PERSONAL REHABILITATION}

I have been identifying the complexity of images connected with group-specific costumes ever since I was first involved in the developments connected with the tourism folklore event called Traditional Costume and Clothing Heritage Days. I was invited to take part in it by the closest colleague of the event's founder. Even during my first meeting with the organizers I foresaw the dilemmas accompanying this kind of work: I arrived exactly when the members of the organizing board were arguing fervently about whether women were allowed to whoop during the procession or not. During my first closer contact with the event, this notable prejudice against whooping in particular made me have second thoughts about the deeper meanings and ideas of this event.

By getting to know the event itself, and the participants' desires and the visitors' reactions, I gradually formed my own idea of the motives for developing the event and the reasons for its preservation and increasing popularity. In an effort to feel what it meant "to be wearing a traditional costume," I put on a traditional costume myself on one of these occasions. My own experience of wearing a dress—a black costume-was very important: a traditional costume is namely not clothing, but a disguise. In this way I put on the power of the meanings that people ascribed to the clothing, and I became part of the ritual, someone else, part of a false identity —of history and its presentation. Doing this, I was aware that this experience would nonetheless be mine and mine alone, like my view of their understanding of this phenomenon: "The sense we make is 'ours', and may or may not coincide with that intended by those whose behaviour it was" (Cohen 1995: 17; cf. Geertz 1975: 5).

Working with the principle members of the board and knowing that they felt that I was trying to get closer to them by wearing a traditional costume, I also began to discover the background the organizers did not reveal to the public. During a notably personal conversation I learned about the circumstances that led to the event itself.

One of the Kamnik locals was behind the initiation of the event, ${ }^{4}$ which at first was only a procession of participants wearing traditional costumes. He was among those that lost a considerable portion of their property for political reasons under communism after the war, and at the same time among those that experienced great distress during the postwar political changes. The townspeople did not know the reasons for his personal trauma, which was also visible on the outside; only his closest colleague did. She had experienced similar pressures and joined him in the initiative to organize the Kamnik traditional-costume festival. ${ }^{5}$ The people promoting the event were supported by their colleagues with similar experiences.

4 This event grew out of an earlier one called the Podgorje Wedding that was carried out by villagers living just outside of Kamnik.

5 Specific details are not provided in order to protect personal information. 
The idea of holding this event was thus a way of reaffirming its initiators among the townspeople and a way for them to seek personal peace; at the same time, the event also reflected broader social needs. Externally, these needs expressed the efforts made by the Kamnik Tourism Association; this was therefore a tourism folklore event that was intended to attract as many people as possible to Kamnik and outwardly promote it and construct their local identity. At the personal level, these needs were different: the idea of "the people of Kamnik taking their original traditional costumes from their chests and showing them to the town," which the organizers presented to me during our conversations as the initiative for the event (Klobčar 1990: 18), had a wider social background and extremely personal features. Many other townspeople had also experienced such humiliation, which often had a political connotation.

Thus on Traditional Costume Day ${ }^{6}$ the upper-class townspeople walked proudly through the town again wearing the old dresses and suits in which they had displayed their ethnic and bourgeois consciousness before the Second World War. They were joined by people from other towns, some wearing their group-specific costumes, and folkdance groups. For a while, the age of the traditional costumes or the quality of old inherited traditional costumes reestablished the hierarchy that the townspeople were used to before the Second World War. It symbolically evaluated the social powers that had lost their status during the political upheaval. The demands for authenticity of clothes were thus not merely demands that related to the group-specific costumes alone, even though they relied on the prewar efforts "for the most authentic traditional costume possible." 7 At the end of the nineteenth century and the beginning of the twentieth century, at the time when they began expressing their ethnic identity by wearing traditional costumes, upper-class townspeople bought well-preserved and richly decorated traditional costumes from the farmers in the countryside.

The folk-costume procession was thus primarily an event for the urban upper class. Even though it was part of efforts to revive tourism in the town, which was increasingly losing long-stay tourism due to new tourism trends, it was nonetheless also an event for the urban upper class: intentionally or unintentionally, it was used to replace the ceremonies they had lost due to the political changes after the Second World War. This included events that emphasized Slovenian identity and included "Slovenian ladies" wearing traditional costumes in order to promote the urban upper class. In addition, they replaced the church processions in which some people had worn their costumes. Because of this, even the processions before the war, especially the ones for Corpus Christi, already included features of

6 The event was initially called Traditional Costume Day.

7 These demands had their roots in neo-romantic trends in ethnology. Its proponents evaluated the originality of costumes before the Second World War and awarded appropriate certificates for them. In 1927, for example, in addition to the "traditional lady" Franja Tavčar, wife of the author and former Ljubljana mayor Ivan Tavčar, other evaluators included the teacher and ethnographer Albert Sič, museum director Josip Mantuani, painter Maksim Gaspari, and teacher and ethnographer Božo Račič. 


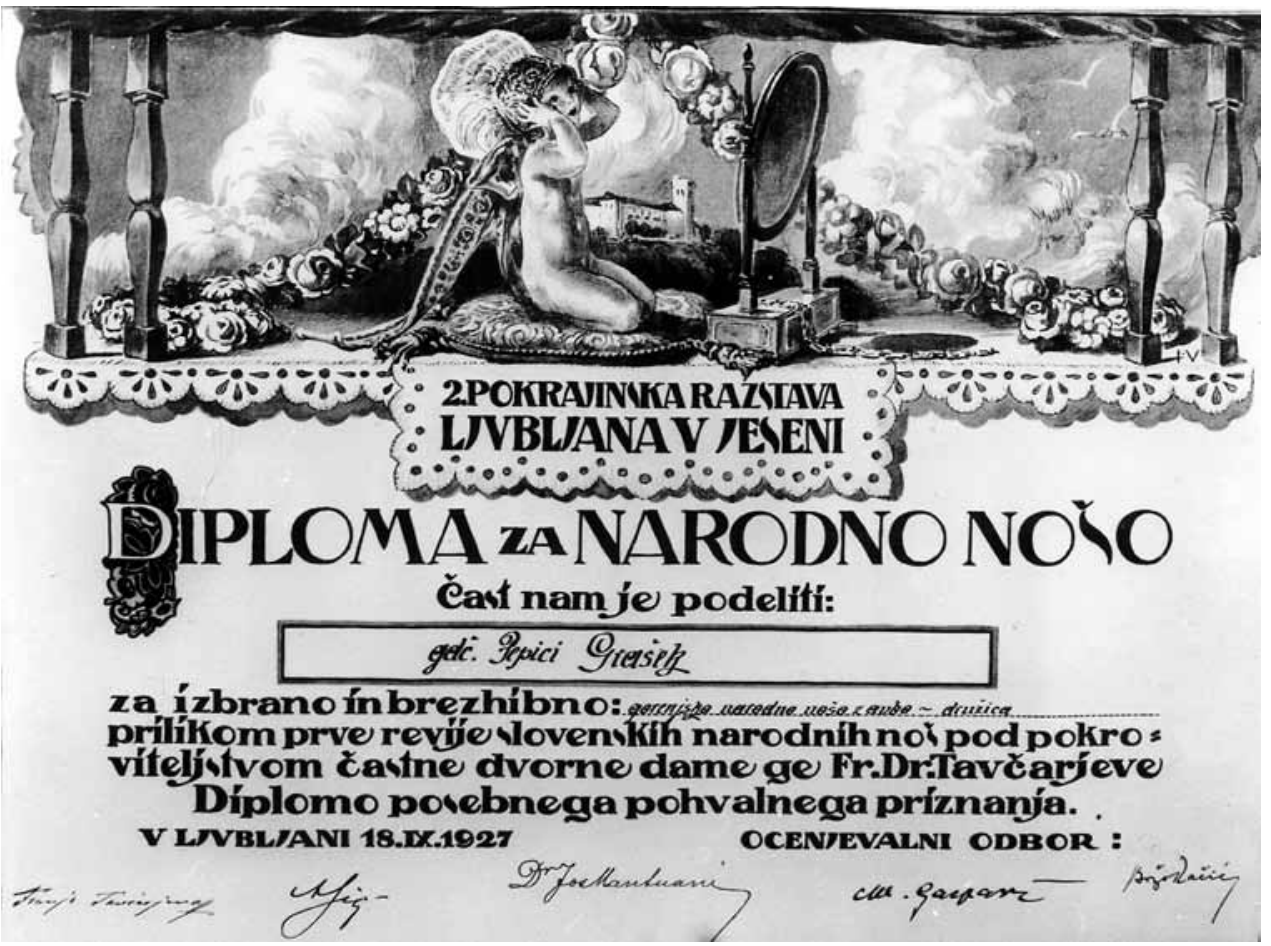

Figure 1 . The demands to determine authenticity expressed by the promoters of the Kamnik event Traditional Costume and Clothing Heritage Days were shaped by the neo-romantic school of ethnography during the interwar period. (Traditional Costume Certificate, 1927, awarded in Ljubljana to a townswoman of Kamnik; original property of Mara Pucelj, Kamnik.)

folklorism. The traditional-costume procession, which from today's perspective may look like an invented tradition (Hobsbawm 1983), fulfilled the need for continuity and a safe affiliation with ethnic identity.

The ban on processions in the town did away with two things: not only the event as a manifestation, but also any expression of religious affiliation; at the same time it also did away with a form of self-promotion by the urban upper class. The role of traditionalcostume festival as an unconscious substitute for the processions has decisively shaped the initial image of the event. Ritualism was present in the very behavior of participants, especially women, who not only had to act decorously but also with dignity. The demands for authenticity were thus connected with the function of group-specific costumes before the Second World War. This was precisely what gave the traditional-costume procession as a folklore event a ritual dimension at its very beginning, even though they did not know or accept this role.

However, ritualism was connected not only with taking part in bourgeois processions before the Second World War, but also with modern developments. Even the festive depiction of the past in the procession gave a greater importance to this event. The similarity 
with the church ceremonies, which were usually also livened up by traditional costumes, only complemented the ceremonial and ritual character of the event. At the same time, the procession represented a politically appropriate form of relying on the traditional values for everyone that denied their religious affiliation for various reasons after the Second World War: it was an extremely suitable ritual substitute. In addition, it also replaced the modern political manifestations that did not find a suitable response among the people, such as, for example, the manifestative revival of the Partisan tradition. This aspect became more evident after the hunters joined the procession in their hunting clothes: the hunters' association also included many adherents to the regime.

The Kamnik traditional-costume festival also had strong political support: Traditional Costume Days brought together political and economic motives or, in other words, features of the East and West (cf. Poljak Istenič 2011). This therefore involved politically supported ritualism that suited both the system's political adherents and its opponents. It also offered both an opportunity to personally escape reality and, along with this, personal therapy.

Despite all the hidden meanings that gave the procession a ritual aspect, traditionalcostume festival was primarily a tourism-folklore event on the outside, seeking to preserve the authenticity of heritage. At the beginning, it also sought to promote its evaluation of authenticity by organizing a competition for the best traditional costume. This very competition reflected both the expectations of the organizers, who hired advisors from the Ljubljana Institute of Ethnomusicology, and the ideas of the participants. The ideas of both differed to the extent that later on the competition was no longer held. After the presentation of the awards, one of the disappointed participants went up the jury members and said "Fuck you! You gave the award to some old costume, but ours are really beautiful and brand new!"

\section{THE EVENT AS A FORM OF PUBLIC ENTERTAINMENT: THE RITUALISM OF A WORLD TURNED UPSIDE DOWN}

At the very beginning, the traditional-costume procession was joined by organized groups and people from nearby places, and their numbers increased strongly over the years. The local Kamniška Bistrica Folkdance Group played an important role in the event because in its own way it raised questions of originality and authenticity, the esthetics of presentation, the relations between traditional and modern values, the freedom of the creative self, and so on (cf. Ceribašić 2003). From the 1960s onwards, increasingly more people could afford to buy traditional costumes due to improved living standards and, at the same time, with urbanization personal initiatives gained increasingly more dimensions. Moving to town created new needs to replace what people had lost when they moved to town, and the event

8 Information provided by the participating ethnochoreologist Mirko Ramovš. 
itself was increasingly gaining the character of a party. It was also supported by an increasing number of musicians participating in the procession and the inclusion of musicians' societies.

Increasingly more organized folkdance groups participated at the event. During communism, groups from abroad created a cosmopolitan impression and groups from other Yugoslav republics highlighted the politically supported formation of links between the Yugoslav peoples. The increasing participation by groups from various Slovenian regions illustrated the diversity and richness of Slovenian heritage. The inclusion of all these groups highlighted the folklore and tourism aspect of the event: because these involved dance groups, those in the procession generally did not feel it to be a dignified experience.

The procession was soon joined by other group-specific costumes, among which the shepherds from the Velika Planina mountain pasture stood out the most. The inclusion of individuals that people knew as folk comedians greatly changed the event's orientation: the shepherd Kati Turk, who also wrote folksongs, performed at the event with her humorous tales. Her presence in the procession thus created a festive atmosphere. In the 1980s, the procession also included a symbolic presentation of old farm chores. It was primarily dedicated to those that had moved to town and were nostalgic for rural life.

Livening up the procession by including entertaining pieces and various images of life and work distant from urbanization caused the event to move away from its former serious ritual image. At the same time, the procession provided an opportunity for the self-promotion of every individual, not just the urban upper class. For many participants, participating in the procession represented the only opportunity to be ever noticed, in which the costume also changed esthetic norms: women whose figures did not meet modern esthetic criteria were the finest examples of traditional-costume wearers in the procession. Doing various chores on the carts introduced humorous images of everyday life to the procession and triggered comments among the spectators; there was increasing communication among the participants as well as between the participants and the spectators, and the event was gaining an increasingly festive character. Communication between the participants wearing costumes and the spectators also increased. At the same time, the festival continued to grow and efforts to make a greater profit opened the door to sales at market stands. The procession was only part of the events taking place, which had a much more relaxed character in costumes than it would have otherwise had.

Thus the procession morphed into a kind of world turned upside down (cf. Fikfak 2005): by wearing costumes, people allowed themselves to do what they would not otherwise, such as whooping by women. Traditional Costume Days thus began replacing the use of costumes: for adults before the Second World War these represented an important means of expressing themselves, and after the war this was mainly intended for children. Wearing costumes was part of carnival processions. Through this, the procession started acquiring completely different ritual features.

The demands to ensure authenticity felt by the event's organizers thus gained new justifications. I was also included in the event myself as part of these efforts. As already 
described, I agreed to take part in this, especially in the interpretative sense: by no means could I take on the role of a judge deciding who could participate in the procession and who could not, nor on how they should behave in the procession. Upon closer contact with people, I soon changed my initial critical attitude towards this topic, which reflected the position of ethnological studies (Ftičar 1984). I thus chose not to get involved in the discussion at the time about women whooping during the procession: I became increasingly aware that the event would express whatever people felt. I performed my role primarily by interpreting the event; by doing this I wanted to draw attention to the fact that the procession not only promoted the image of the rural culture, but also the urban culture and the image about it by reviving what had already been revived, in which people manifested themselves.

Doing this, I came to realize that the strong desire for authenticity was typical of people that had already been included in the evaluation of "true" traditional costumes before the Second World War. The certificates for authentic traditional costumes awarded at events promoting authentic traditional costumes also served this purpose. ${ }^{9}$ These were also people that could not accept any behavioral changes in the procession; this mainly involved changes in women's behavior that some of the women participating could not accept.

The demands for establishing and ensuring authenticity thus came from the ranks of the very participants or organizers - that is, the ranks of those that wore traditional costumes, which problematizes today's view on the relationship between an ethnologist and the participants or designers of tourism folklore events: "The researchers that have examined folklorism have found it difficult to avoid evaluating it; and only rarely has it been judged from the perspective of its performers. Most often, researchers have been critical toward the phenomenon; they most highly valued the examples of folklorism that were most similar to the assumed 'original,' or whose reconstruction was the most 'professional.' It is evident that they assumed the a priori position of connoisseurs of the original, indigenous cultural phenomenon or its 'proper form'; ethnology, or its appropriately educated and trained mediators, became the obligatory authority for 'proper,' 'professional' reconstruction and interpretation of these phenomena or acted as the necessary authority for appropriate scholarly reconstruction and interpretation of these phenomena" (Poljak Istenič 2011: 75). The lesson provided by the anonymous phone call had a completely different message.

\section{THE EVENT AS A LIVING MUSEUM: THE RITUALISM OF PRESENTING CLOTHING HERITAGE}

Introducing a relaxed atmosphere to the procession, market stands, and performances by pop-folk groups, which complemented the program when the event expanded to several days, moved the event away from its founders' initial plans. In the 1980s, the procession

9 One of these certificates has also been preserved in the collection of a member of the event's organizing board, Mara Pucelj. 
included a group of majorettes from Ljubljana, who performed in short skirts and coordinated their performance with music played by a group of musicians. The inclusion of the majorettes, who were soon replaced by a local group, strongly divided public opinion. Some people thought their performance was extremely offensive because they believed it completely devalued the procession; others thought the majorettes were an appropriate addition to the event.

With the political thaw that preceded Slovenia's independence, some of the initial motives for holding the event disappeared. The urban upper class regained social power and the ideological pressures loosened up, which soon resulted in permission to hold the procession in town. Under the new social circumstances, the commercial aspect of Traditional Costume Days became increasingly important, which moved the event away from the initial ideas of its organizers and numerous participants. Sharp criticism appeared in the local newsletter, aimed primarily at the market stands. For example, a 1988 review titled “Traditional Costume Days or a Gypsy Fair” read as follows: "The magnificent Sunday procession featuring hundreds of traditional costumes, ingeniously decorated carts, and accordion players really cannot compensate for all the dissatisfaction caused by intrusive peddlers." The following year they even criticized the event's name along these lines_- "Folk Costume Day or Folk Misery Day"_claiming the following: "This is how we could name the event that embarrassed the people of Kamnik from 8 to 10 September. There were truly many traditional costumes in Sunday's procession” (Hieng 1995: no page).

The finding that "there were truly many traditional costumes" became the main criterion of this event. The procession was turning into an extremely colorful parade in which individuals' various motives for participation stood out in various ways. In addition to the motives that were clear in previous decades and which are continuously joined by new entertaining scenes, new impulses have sprung up. Social polarization added the aspect of a conservative political component to the locally organized traditional costumes: the traditional-costume societies, which usually liven up the church ceremonies in their local area, also supervise the authenticity as they perceive it, and the level of dignity in their performances, including those at the Kamnik event. Their performances often display the very ritual dignity that could be seen at this event at the very beginning.

The organizers or members of the Association of Cultural Organizations and the Public Fund for Cultural Activities began complementing this event with exhibitions explaining and reconstructing various images of past clothing culture, and at the Public Fund's initiative and under its professional supervision; part of the procession features reconstructions of traditional costumes that did not gain the status of group-specific costumes in the ethnic self-awareness process. This part of the procession functions as a living museum and thus primarily has an educational role; it is separated from the rest of the procession, commented on by a moderator on the stage.

However, the separation of the professionally prepared educational part from the rest of the procession, in which original Kamnik traditional costumes play a special role, is 
not the only indication of all the variety in the procession. The participants in Traditional Costume Days differ greatly in the way they experience their performances: some of them are very serious and still experience the procession as a ritual, some have fun like in a Carnival procession, and some experience it as a historical show. The seemingly uniform group of traditional costumes is thus an extremely heterogeneous community with all elements of the urban character (Cohen 1995: 24-26).

However, the diversity of meanings characterizes not only the participants of the procession, but also its spectators. Some see the images of living national history in everything that is presented, some understand it as a street party or a village festival, and some consider it an extremely pleasant and colorful experience. With some, this involves bringing back memories of their childhood and their singing together, some regard it as an opportunity to buy things at the market stands, which are part of the event, and some use it as an escape from everyday life and problems - or, as one of the visitors told me at this year's event: "You know why I'm here? Because I've been at an impasse with my wife for the last thirty years!"

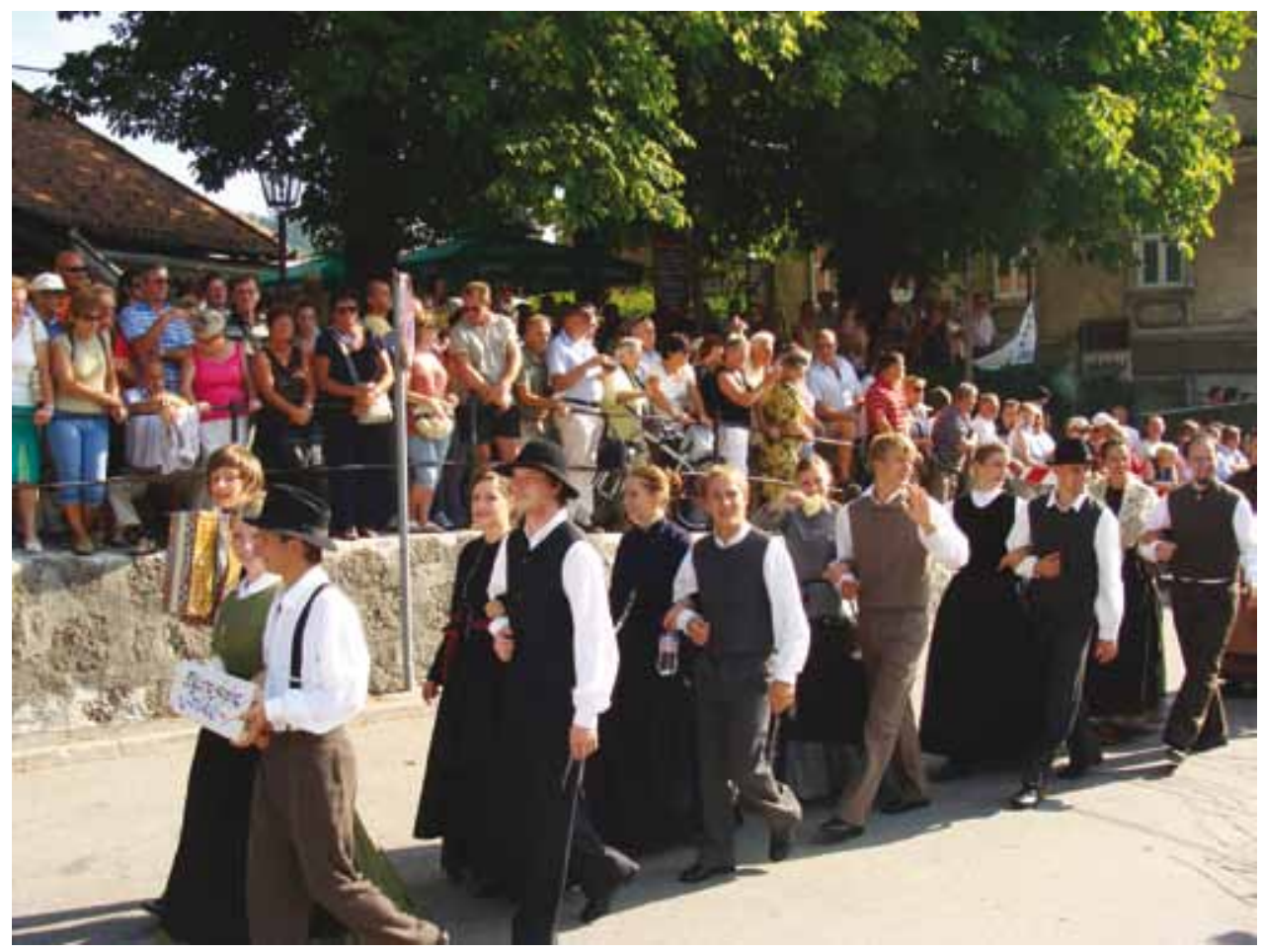

Figure 2. The festive parade of participants in the Kamnik event wearing group-specific costumes shows highly varied motivation for inclusion in it, as well as various understandings of authenticity. Scene from the central part of the Traditional Costume and Clothing Heritage Days in Kamnik, 2011. (Photo: M. Klobčar) 


\section{CONCLUSION}

As suggested by the conversations I had with the participants in Traditional Costume and Clothing Heritage Days, and my observation of the event, the ideas of group-specific costumes differ greatly, as do the ways of implementing these ideas. The participants share different opinions about one another, in which their views differ the most regarding the authenticity of the original. When I was condemned for taking the photo of the girl riding a bike in a traditional costume, this also condemned the girl that sat on a bike and rode along the street for fun. Her sin was the fact that she was no longer part of ritually staged history: people saw her the way she really was — that is, capable of relativizing her role in a humorous way, rather than being part of history, in which the current context cannot be seen.

The role of researchers in folklorism has long been relativized, in which their a priori position is primarily problematized (Bendix 1997; Poljak Istenič 2011). Researchers should thus step down to the same level as the informants, or as Johannsen puts it, "it is a postmodernist dictum that ethnographers should place themselves on an equal footing with informants. In order to achieve that goal, it is necessary to disperse authority, to establish a dialogue, to let the "natives" voices be heard" (Johannsen 2001: 346).

In this regard, Kamnik Traditional Costume Days bring up a very interesting issue. The informants (i.e., the participants, advisors, and spectators) experience the event and its cultural phenomena very differently or at different levels. These discrepancies also (or primarily) include the views on the event's authenticity. The informants' opinions are thus extremely different, so one cannot talk about a simple relation between the researchers and the participants, but the interconnection of these relations and different relationships between the researchers and participants that have different opinions. There are different reasons for participating in the traditional-costume procession connected with the attitude to presenting heritage; similarly, there are also different evaluations of the role and work of researchers. For example, the organizers and many participants expect ethnologists to professionally evaluate how close both the clothes and singing or playing gets to the ideal; they want them to evaluate whether their shoes match their clothes and whether their kerchiefs are tied properly, some ask them for specialized literature and the pattern, so that they can make their own costumes, and so on. Others do not need their evaluation or think it is not necessary; they are happy with the colorful character of the event and a suitable degree of entertainment. The researchers' presence bothers some because they feel they can make their own assessments, whereas others do not need the view of the Other because for them the event is a form of relaxation, in which observers and their cameras are nothing but a nuisance. The informants (the participants and the spectators) thus experience the event and the researcher's role at different levels. But what level should the ethnologist descend to in order to be equal to the informants? 
As can be seen from the example of the Kamnik event, the participants or the informants themselves mostly ensure that their ideas are properly implemented. In this regard, the most important role is primarily played by those participants to whom traditional

costumes and wearing them means a great deal either because of their family tradition connected with various reasons for wearing group-specific costumes, or because they could only afford to buy a new costume with great difficulty. Special meanings are also reflected by wearing costumes, which has acquired a ritual aspect for many people. Especially because of this ritual character, which creates the untouchable from tradition by adding special meanings, they can assume the moral right to judge those that observe them inappropriately in this role.

Sometimes the informants provide the researcher an opportunity to come close to them in the field for other reasons as well. For example, when I was recording the singing groups at this year's "Upper Carniolan Festival of Singers of Folk Songs and Musicians Playing Folk Tunes," as it is referred to in Slovenian (and which is part of Traditional Costume and Clothing Heritage Days), my attention was caught by a middle-aged man that kept singing along with the performing singers. While I was recording the singing, he told me about his childhood and how he used to clean the train cars at the Kamnik railway station with his mother as a child using a carbide lamp and singing to keep from feeling afraid. The songs performed on the stage reminded him of his childhood and he could not care less whether this was an event or spontaneous singing; so sang along spontaneously with the singers on stage and supplemented his singing with comments. He apparently felt he could confide in me during our conversation and, when I moved closer to the stage to make a better recording of the singers, he came by and in a somewhat lower voice said something that waitresses often hear from their tipsy guests. The formality of the event was the least of his concerns.

\section{REFERENCES}

Bendix, Regina

1997 In Search of Authenticity. Madison: University of Wisconsin Press.

Ceribašić, Naila

2003 Hrvatsko, seljačko, starinsko i domaće: Povijest i etnografija javne prakse narodne glazbe u Hrvatskoj. Zagreb: Institut za etnologiju i folkloristiku.

Cohen, Anthony P.

1995 The Symbolic Construction of Community. London: Routledge.

Geertz, Clifford

2007 The Interpretation of Cultures. New York: Basic Books.

Fikfak, Jurij

2003 Re-constructed rituals between Reality and Imagination. In: JeffBernard, Jurij Fikfak, Peter Grzybek (eds.), Text \& Reality/Textઐ Wirklichkeit. Ljubljana: Založba ZRC, ZRC SAZU, 79-92. 
Ftičar, Marija

1984 Etnolog v areni turizma. NR, Naši razgl 33/10 (777): 290.

Hobsbawm, Eric

1983 Introduction. Inventing Tradition. In: Hobsbawm and Ranger (eds.) 1983, 1-14.

Hobsbawm, Eric J. and Terence O. Ranger (eds.)

1983 The Invention of Tradition. Cambridge: Cambridge University Press.

Johannsen, Agneta M.

2001 Applied Anthropology and Post-Modernist Ethnography. In: Alan Bryman (ed.), Ethnography, Volume 3. London: Sage Publications: 328-349.

Klobčar, Marjanca

1990 Kamnik in narodne noše med izročilom in turizmom. 20. dnevi narodnih noš. Kamnik: Turistično društvo Kamnik, Zveza kulturnih organizacij Kamnik, 5-32.

1995 Vsi obrazi “narodnih noš.” In: Tone, Ftičar et al., 25. dnevi narodnih noš. Kamnik: Občina Kamnik, no pagination.

Klobčar, Marjanca

$1993 V$ samivsvatovskem bleščiš. Narodna noša kot izročilo. Kamnik: Zveza kulturnih organizacij Kamnik, no pagination.

Knific, Bojan

2008 “Ko vnošo se odenem...."Vprašanjapripadnostnega kostumiranjasposebnimpogledom na kostumiranje narodno-zabavnih ansamblov. (= Knjižnica Glasbnika SED 41). Ljubljana: Slovensko etnološko društvo.,

2010 Folklornikom s(m)o vzeli noše: kostumiranje folklornih skupin - med historično pričevalnostjo in istovetnostjo. Ljubljana: Založba ZRC, ZRC SAZU.

Poljak Istenič, Saša

2011 Text and Context of Folklorism. Traditiones 40/3: 74-82.

\section{RITUALIZEM - REFLEKSIJA DRUŽBENIH TRANSFORMACIJ IN RAZISKOVALČEVE (-GA POMANJKANJA) MOČI}

Izhodišč za razmislek je konflikt, ki ga je sprožila objava fotografije dekleta na kolesu, oblečenega $v$ pripadnostni kostum, ki sem jo posnela na eni od prireditev Dnevi narodnih noš in oblačilne dediščine v Kamniku. Izrazito negativni odziv skupine udeleženk na objavo fotografije, skaterim sem bila soočena, sem skušala razumeti kot izraz, ki odseva predstave udeležencev o pripadnostnem kostumiranju in o sami prireditvi, hkrati pa mi je ponujal izziv za lastni razmislek o sami prireditvi in vlogi raziskovalca v njej.

Ob lastnem sodelovanju pri prireditvi se mi je ta vloga izostrila na dveh ravneh: po eni strani raziskovalec nastopa v vlogi opazovalca in interpreta, po drugi strani pa na željo prirediteljev tudi $v$ vlogi svetovalca. Prav neposredni stik z razhajanji pogledov tako prirediteljev kot udeležencev, $s$ katerim sem se soočala, mi je omogočal podrobnejsi upogled v genezo prireditve in soočenje s pomeni, ki so vodili v njen nastanek, jo ohranjali, dopolnjevali in spreminjali.

Zamisel za prireditev, ki se je sicer delno zgledovala po predhodni prireditvi Podgorska ohcet, je bila poseben način vnovične družbene afirmacije njenega pobudnika. Oprta je bila na sorodna prizadevanja njegovih neposrednih sodelavcev, ki so s političnim preobratom izgubili družbeni 
ugled. Povorka je pomenila simbolično nadomestilo za izgubljeni družbeni položaj tudi številnim udeležencem, predvsem meščanom. V prvi vrsti je bila torej meščanska prireditev. $Z$ njo so namreč bivši meščani nadomeščali slovesnosti, ki so jih izgubili s političnimi spremembami po drugi svetovni vojni. S povorko narodnih noš, ki je z današnjega stališča navzven morda videti kot izmišljena tradicija, je bila izpolnjena potreba po kontinuiteti, po varni pripadnosti narodnemu. Prireditev je kot nadomestilo za procesije in predvojne mešcanske prireditve že v začetku dobila poteze ritualnega. Ritualnost pa se ni povezovala le s sodelovanjem v meščanskih procesijah oziroma sprevodih pred drugo svetovno vojno, temveč tudi sodobnim dogajanjem: povorka je pomenila politično primerno obliko opiranja na tradicionalne vrednote za vse tiste, ki so po drugi svetovni vojni iz raznih razlogov zanikali versko pripadnost, saj je bila zelo ustrezno obredno nadomestilo. Šlo je torej za politično podprto ritualnost, ki je ustrezala političnim somišljenikom sistema in njegovim nasprotnikom hkrati. Enim in drugim je ponujala tudi možnost osebnega bega pred realnostjo, s tem pa tudi osebne terapije.

Kljub vsem skritim pomenom, ki so povorki dajali razsežnosti ritualnega, pa so bili Dnevi narodnih noš navzven predvsem turistično-folklorna prireditev, ki si prizadeva za avtentičnost izročila. Hkrati je prireditev odražala širše družbene potrebe, saj naj bi kot turistično-folklorna prireditev $v$ Kamnik privabila čim već ljudi in ga promovirala navzven. Priseljevanje v mesto so sprožile nove potrebe za nadomeščanje tistega, kar so ljudje ob priselitvi v mesto izgubili, sama prireditev pa je dobivala vedno bolj zabavni značaj.

Vpovorko so se vse bolj vključevale organizirane folklorne skupine in druge skupine pripadnostno kostumiranih udeležencev. Popestritev povorke z zabavnimi vsebinami in z raznimi podobami življenja in dela, odmaknjenega od urbanizacije, je prireditev postopno oddaljevala od nekdanje resne ritualne podobe. Hkrati je povorka nudila možnost za samopromocijo slehernemu posamezniku, ne le meščanom. Številnim udeležencem je vključitev vanjo pomenila edino priložnost, da so bili kdaj opaženi. Praznovanje se je širilo in povorka je bila samo del prireditvenega dogajanja, ki je bilo v preobleki veliko bolj sproščeno, kot bi bilo sicer. S tem je sprevod dobil tudi značilnosti obrnjenega sveta, torej nove podobe ritualnega. Prizadevanje za avtentičnost, kot so jo razumeli organizatorji prireditve, je zato dobivalo nova opravičila in utemeljitve.

Organizatorji - sodelavci Zveze kulturnih organizacij oziroma Javnega sklada za kulturne dejavnosti so prireditev začeli dopolnjevati z razstavami, namenjenimi razlagam in rekonstrukcijam različnih podob pretekle oblačilne kulture, del povorke pa so na pobudo in pod strokovnim vodstvom iste službe postale tudi rekonstrukcije tistih noš, ki v procesu narodnega samozavedanja niso dobile statusa pripadnostnega kostumiranja. Ta del povorke ima kot živi muzej predvsem izobraževalno vlogo.

Udeleženci povorke ob Dnevih narodnih noš in oblačilne dediščine se zelo razlikujejo po motivih za vključevanje in $v$ doživljanju svojega nastopa. Mnogovrstnost pomenov pa ne zaznamuje le udeležencev povorke, temveč tudi njene gledalce: nekateri v vsem prikazanem vidijo podobe žive nacionalne zgodovine, drugi jo razumejo kot ulično zabavo ali gasilsko veselico, tretjim je izredno lepo in pisano doživetje, ki se po prireditvi nadaljuje z ulično zabavo.

Predstave udeležencev o pripadnostnem kostumiranju so torej zelo raznolike, različni pa so tudi 
načini njihovega uresničevanja. Udeleženci imajo različna mnenja drug o drugem, pri čemer se najbolj razhajajo v pogledih na zvestobo "izvirniku", torej v pogledih na avtentičnost. Zahteve po ugotavljanju in zagotavljanju avtentičnosti torej prihajajo iz vrst samih organizatorjev in udeležencev, iz vrst tistih, ki se pripadnostno kostumirajo, to pa problematizira današnji pogled na razmerje med etnologom in udeleženci oziroma oblikovalci turistično-folklornih prireditev. Temeljna dilema, povezana $z$ vlogo raziskovalca $v$ folklorizmu, namreč relativizira predvsem njegovo apriorno pozicijo: raziskovalec naj bi stopil na raven informatorjev. Kamniška prireditev Dnevih narodnih noš in oblačilne dediščine $v$ tem pogledu odpira zelo zgovorno dilemo. Informatorji-torej sodelujoči v prireditvi, njeni usmerjevalci in gledalci-prireditev in njene kulturne fenomene doživljajo na zelo različne načine oziroma na različnih ravneh. Med ta razhajanja sodijo tudi - ali predvsem - pogledi na avtentičnost prireditve. Presoje informatorjev so torej zelo različne, zato ne moremo govoriti o enostavnem razmerju med raziskovalcem in udeleženci prireditve, temveč gre za prepletanja teh relacij, za različnost razmerij med raziskovalcem in različno mislečimi udeleženci. In tako kot so različni razlogi za vključevanje v povorko narodnih noš, vezan na odnos do prikazovanja dedišcine, tako so različne tudi presoje vloge in dela raziskovalca. Na katero raven naj se torej spusti etnolog, da bo enak informatorjem?

Kot je videti iz primera kamniške prireditve, pa za uveljavitev svojih predstav večinoma poskrbijo udeleženci sami. Pri tem je najpomembnejša predvsem vloga tistih udeležencev, pri katerih je pripadnostno kostumiranje del ritualnega. Ti iz izročila $z$ dodajanjem posebnih pomenov ustvarjajo nedotakljivo in si pogosto jemljejo strokovno in moralno pravico, da sodijo tiste, ki jih $v$ tej vlogi neustrezno opazujejo, tudi same raziskovalce.

Dr. Marija Klobčar, višja znanstvena sodelavka, Glasbenonarodopisni inštitut ZRC SAZU, Novi trg 2, 1000 Ljubljana, mklobcar@zrc-sazu.si 